\title{
Mere impediments? A second thought on the role of social boundaries in self-organisation of the global collective intelligence on the Earth
}

\author{
Marta Lenartowicz $^{1, *}$ \\ ${ }^{1}$ Vrije Universiteit Brussel, Global Brain Institute / Krijgskundestraat 33, B-1160 Brussels, Belgium \\ E-Mails: marta.lenartowicz@mac.com
}

* Author to whom correspondence should be addressed; Tel.: +32-2-640 67 37; Fax: +32-2-644 0744 Accepted: March 32015

The vision of the Global Brain (Heylighen 2007, 2014), a genuine, unstoppable intelligence arising from the accelerating interconnectivity of individuals and their technological extensions, feels like the exact opposite of the world as it used to be, and - in many respects - still is today. Today, our interconnectivity is still largely impeded. What seems to constrain it most is the influence of social boundaries, which divide us into representatives of various hierarchy ranks, nations, religions, political orientations, etc. It might be tempting to agree that such boundaries have brought about more evil than good, have caused much suffering, and are top contributors to waste of human intelligence. And yet, even approaching the very topic of social boundaries we will end up representing and advocating for various paradigms, disciplines, and schools of thought. Any topic, any event, anything at all, can trigger us to draw a new line, attempt to convince our neighbours to stay at our side of the resulting boundary, and see the ones who choose not to as mistaken or ignorant. When personally engaged in such an activity we will not see ourselves as impeding humanity, we will argue the opposite.

One possible resolution of the above paradox may be to divide social boundaries into two distinct kinds: the limiting and imprisoning ones (national, hierarchical, etc.), which are to be gotten rid of, and the ad hoc constructed and freely abandoned ones, which humans set forth as their temporary means of collective self-expression, and which contribute to the advancement of the global intelligence (e.g. Weinbaum \& Veitas 2014). Another approach is to see both types of boundaries as unnecessary, and to foresee their transcendence and merger until the only one ultimate boundary - that of the globe - is left (e.g. Heylighen 2007). I propose to explore yet another perspective, which assumes that the basic 
formative mechanism of all social boundaries - be it the old-fashioned, modern, or postmodern onesis actually supportive to the emergence of the collective global intelligence.

I argue that dividing people and constraining their options, as deteriorating and undesirable as it is, is only a side effect of a more profound evolutionary function of social boundaries, which is to produce and fortify new collective, distributed, and disembodied loci of cognition. Not underestimating or justifying the individual costs (which, hopefully, humanity is learning to bypass), I propose that the underlying mechanism responsible for the formation of social boundaries, being essentially semiotic, not topological, resembles more a formation of an individual cell, than that of a multicellular organism. A social boundary does not arise from clustering of human agents (although this frequently co-occurs), but from the acquirement of an operational closure by an interrelated set of meanings (Luhmann 1995). The resulting cognitive membrane yields a new coherent worldview (Aerts et al. 1994, Vidal 2008), through which a new representation of the world is obtained, new challenges (Heylighen 2012) identified, and new type of action is enabled.

The mechanism is responsible for production of both kinds of social boundaries: the ones that are currently considered obsolete (nation states, social classes, genders, etc.), and the ones we are ourselves busy with sustaining (schools of thought, social movements, aspect systems of the society, etc.). The despised constraining of individuals, which invited the metaphor of a multicellular organism, was due to the fact that until recently humans were the most reliable processors of the semiotic operations, which are needed for continuous maintenance of a worldview membrane. The most certain way to ensure their involvement - from the point of view of the emergent social locus of cognitionwas to 'own' them totally, and to disallow any opting out. But living humans were never the only carriers of a social boundary - as important were other catalysts of meaning present, such as written texts, visual symbols, music, etc.- and each major advance in this domain brought humans a new opportunity for becoming more free, should they dare to. E.g. once the social boundary of an industrial factory could be laid on contracts and operational procedures, it did not demand to own a human from his birth to death (as a social class did).

Since the internet-based communication technologies start to be able to sustain almost all operations needed for a worldview membrane to exist, humans seem to be in a position to pursue their individual freedom to an extent unthought of before. Today, a continuous operation of a cognitive membrane may be well enabled by an website alone, providing that from time to time a human being chooses to interact with it and to leave a trace of this activity for other agents. As a result, social boundaries that emerge nowadays can afford to be easily overlapped, and easily mixed, and easily crossed by individual minds. But semiotically they are not fuzzy at all. A cognitive membrane produced by, say, the Occupy movement yields as complete a worldview, identifies as much new challenges, and motivates as much action, as the emergence of a kingdom used to in the past. Even when the resultant loci of cognition become ever more collective, distributed, and disembodied, it does not mean, thus, that the essential evolutionary function of social boundaries is getting lessened.

By reconceptualisation of the mechanism of social boundary formation I invite a second thought on the role that social boundaries play in the emergence of the global collective intelligence. As their 
products evolve, they contribute to the emergence of more and more instances of intelligent cognition, localised ever further away from biological embodiment. This mechanism is, I believe, one of important facets of the advancing self-organization of the Global Brain.

\section{References}

1. Aerts, D., Apostel L., De Moor, B., Hellemans, S., Maex, E., Van Belle, H., Van der Veken, J. (1994) World Views. From Fragmentation to Integration. Brussels: VUB Press. Url: http://www.vub.ac.be/CLEA/pub/books/worldviews.pdf

2. Heylighen, F. (2007). The Global Superorganism: an evolutionary-cybernetic model of the emerging network society. Social Evolution \& History, 6(1), 58-119.

3. Heylighen, F. (2012). Challenge Propagation: a new paradigm for modeling distributed intelligence. GBI Working 2012-01. Uaper http://pespmc1.vub.ac.be/Papers/ChallengePropagation.pdf

4. Heylighen, F. (2014). Return to Eden? Promises and Perils on the Road to a Global Superintelligence. In B. Goertzel \& T. Goertzel (Eds.), The End of the Beginning: Life, Society and Economy on the Brink of the Singularity.

5. Luhmann, N. (1995). Social systems. Stanford: Stanford University Press.

6. Weinbaum R., D., \& Veitas, V. (2014). A World of Views - Fragility and Antifragility in Sociotechnological Evolution. In Jennifer Wilby, Stefan Blachfellner, Wolfgang Hofkirchner (Ed.), Civilization at the Crossroads Response and Responsibility of the Systems Sciences - European meetings on Cybernetics and System Research (pp. 757-762).

7. Vidal, C. (2008). Wat is een wereldbeeld? (What is a worldview?). In Van Belle, H. \& Van der Veken, J., Editors, Nieuwheid denken. De wetenschappen en het creatieve aspect van de werkelijkheid, in press. Acco, Leuven. 